\title{
Chironomidae from Eastern Amazon: Understanding the differences of land-use on functional feeding groups
}

\author{
Kathia C. SONODA,${ }^{1 *}$ Josinete S. MONTELES,${ }^{1}$ Anderson FERREIRA, ${ }^{3}$ Pedro GERHARD ${ }^{2}$ \\ ${ }^{1}$ Embrapa Meio Ambiente, Rod SP 340, km 127.5, Jaguariúna, SP, CEP 13918-110; ${ }^{2}$ Embrapa Territorial, Av. Sd. Passarinho, 303, \\ Campinas, SP, CEP 13070-115; ${ }^{3}$ Universidade Federal da Grande Dourados, Faculdade de Ciência Biológicas e Ambientais, Rodovia \\ Dourados-Itahum, Km12, Cidade Universitária, Caixa Postal 364, Dourados, MS, CEP 79804-970, Brazil \\ *Corresponding author: kathia.sonoda@embrapa.br
}

\begin{abstract}
Deforestation for agricultural purposes is the most dangerous human action against the conservation of the Brazilian Amazon Forest; its rates reached almost $20 \%$ of the original forested area. Many studies have been conducted on Chironomidae systematics and ecology over the Amazon biome, but most concerned the Central Amazon, while little is known about Chironomidae diversity and the effects of land development and agriculture intensification on the aquatic biota from Eastern Brazilian Amazon. The present study analyzed the effects of different land-use and land-cover on Chironomidae assemblages. Land-Use and Land-Cover (LULC) at the riparian zone were assessed from satellite imagery and three categories were defined: Forest, Secondary (Capoeira) and Agriculture. Ten catchments were selected: two for Forest, five for Agriculture and three for Secondary. For each catchment we characterized habitat and sampled insects. We hypothesized that i) the assemblage taxonomic richness will change across different land uses on riparian zones and ii) feeding functionality (FFG) is a better information than taxonomic resolution to show the importance of LULC upon stream. A total of 20,884 individuals were sampled from the streams, abundance was higher in Agriculture streams. Corynoneura (18.4\%), Pentaneura (14.6\%) and Rheotanytarus $(14.0 \%)$ were the most abundant genera in Agriculture streams; Corynoneura (17.8\%), Caladomyia (13.6\%), Paratanytarsus (13.1\%) and Beardius (10.9\%) dominated Forest streams; Goeldichironomus (25.9\%), Rheotanytarus (17.6\%) and Polypedilum (13.2\%) dominated Capoeira streams. Regarding FFG, gatherers were the most numeric abundant in Forest $(50.3 \%)$, followed by filterers $(38.7 \%)$, predators $(6.6 \%)$ and shredders $(4.2 \%)$. In Capoeira, filterers were the main FFG (61.1\%), gatherers (27.9\%), predators (7.7\%) and shredders (3.3\%). In Agriculture streams, predators, filterers and gatherers had close numeric participation, $34.9 \%, 32.4 \%$ and $32.2 \%$, respectively. Shredders performed a smaller fraction ( $0.4 \%)$. In Forest and Agriculture, scraper's participation was under $0.2 \%$, while it was absent at Capoeira. Permutation tests showed significant differences among assemblages, based on numerical abundance of genera and on functional feeding group data. Even though, shredders showed a discrete participation in all three LULC, it was statistically significant higher at Forest streams when compared to Agriculture ones. Our study was able to demonstrate taxonomic differences of all LULC analyzed and it also showed the importance in considering the feeding behavior to understand the effects of land-use and land-covers changes.
\end{abstract}

Key words: Rainforest; land-cover; watershed management; aquatic insects; agriculture; Neotropical.

Received: February 2018. Accepted: September 2018.

This paper was presented at the $20^{\text {th }}$ International Symposium on Chironomidae, Trento, Italy, 2-8 July 2017.

Session: Ecology and Biomonitoring.

\section{INTRODUCTION}

Deforestation for agricultural purposes is the most dangerous human action against the conservation of the Brazilian Amazon Forest (Coe et al., 2009); currently reaching almost $19 \%$ of the original forested area (Aguiar et al., 2016). Deforestation increased again after a decade of stability since the Brazilian Forest Law has been changed recently (Brasil, 2012). The consequences of the historical deforestation begin to show up in the last years, even though the alteration in rainfall and water balance, changes on atmospheric chemistry, wide range of varying temperatures on the seasons were foreseen long ago (Ojima et al., 1994).

It is also expected that the change on climate will impact forest evapotranspiration which is an important source of atmospheric moisture that is recycled as precipitation regionally and also over the subtropical La Plata basin (Eltahir and Bras, 1994; Zemp et al., 2014; Zemp et al., 2017). To decrease the climate change effects, the restoration of deforested areas to intact ecosystems and their functions is a need and also a challenge (Lester and Boulton, 2008). Understanding the impact of land-use and land-cover (LULC) over aquatic insects is a key step for further ecosystem restoration projects.

Chironomidae have been described as the most abundant aquatic family at the macroinvertebrate communities sampled around the world (Ferrington, 2008); their importance is recognized as their role as food source item, 
either as prey or as predator, acting on the conversion of organic material to animal protein (Armitage, 1995; Maasri et al., 2008) to mention a few. Moreover, the importance of analyzing traits is highlighted by some authors (Cummins et al., 2005; Merritt et al., 2017) because they demonstrate the ability of the species to deal with environmental problems and opportunities (Verberk et al., 2013).

Those assumptions based our goal to analyze the Chironomidae assemblages from streams reaches bordered by different riparian vegetation (Forest, secondary forest named capoeira - and agriculture) over assemblage taxonomy and trait information based on functional feeding group (FFG). Thus, we sought to understand which assemblage information is the most effective to respond the land-use and land-cover alteration.

To accomplish that goal, we surveyed ten streams reaches differing in local riparian land-use and the numerical abundances of taxon and feeding categories of Chironomidae assemblages. We hypothesized that i) the assemblage taxonomic richness will change across different land-use and land-covers on riparian zones and ii) functional feeding group is a better information than taxonomic resolution to show the importance of LULC over the stream biota.

\section{METHODS}

\section{Study area}

The study was focused on the Northeastern region of Pará State. This region covers over $50,000 \mathrm{~km}^{2}$ East of the Araguaia-Tocantins drainage, and the Northern lowlands areas are drained by several river drainages in the Brazilian Amazon (Fig. 1A). The climate in the study area is tropical, varying from $A m$ (monsoon) to $A f$ (equatorial) in the Köppen-Geiger climate classification. Mean summer (July) temperature is $32.2^{\circ} \mathrm{C}$ and mean winter temperature is $21.7^{\circ} \mathrm{C}$, while the mean annual precipitation varies from 2,302.5 to 2,857.4 mm (Pachêco and Bastos, 2011). Landuse and land-cover in the study area (Fig. 1A) is a mosaic composed mostly of varied Capoeira seral stages of native vegetation patches ('capoeira' - fallow stages of the slashand-burn, itinerant agriculture system; mostly resulting from clearcutting former capoeira, or native forest remnants), pastures, small agriculture fields and forest remnants (Watrin et al., 2009, Almeida et al., 2010).

\section{Site selection, site characterization, sampling and sample processing}

Four sampling areas were selected: two (1 and 2) were located in the Marapanim River watershed and two (3 and 4) in the Capim-Guamá River drainage (Fig. 1). Areas 1 and 3 were selected as agricultural watersheds; areas 2 and 4 were forest fragments in near pristine condition in the range of 1000 to 2000 hectares (Fig. 1B). Catchment delineation was based on a 30-m Digital Terrain Model, and resulted in segmentation of 100-600 hectares such hydrological units. In each catchment, the lowermost 150 $\mathrm{m}$ long stream reach was selected for physical and biological measurements. The selection of the ten catchments was based on LULC dominance on the $30-\mathrm{m}$ wide riparian areas of the sampling reach, into three categories: (1) Forest (5 streams), (2) Capoeira (2 streams) and (3) Agriculture (3 streams). Catchment drainage area and Horton-Strahler stream order were computed on a GIS environment. Channels discharges were measured with a digital flowmeter using the area velocity method (Gordon et al., 2004). Each stream was sampled once, from July to October 2010, during the dry season. Streams names, characteristics of the sampling sites and catchments were informed in Tab. 1 .

Tab. 1. Sampling sites and catchment characteristics in the Eastern Amazon, Brazil. Coordinates are projected on the UTM system, datum WGS84, zone 23S.

\begin{tabular}{lllllll} 
Stream name & Latitude & Longitude & DCs & HS & CD & DA \\
Muquem & 231,584 & $9,771,106$ & $\mathrm{a}$ & 2 & 0.076 & 222.1 \\
\hline Areia & 232,110 & $9,771,330$ & $\mathrm{a}$ & 1 & 0.029 & 130.7 \\
\hline Haras & 211,447 & $9,893,014$ & $\mathrm{c}$ & 1 & 0.029 & 119.0 \\
\hline Pardal & 209,695 & $9,887,742$ & $\mathrm{f}$ & 2 & 0.030 & 118.5 \\
\hline Tomé & 210,773 & $9,886,056$ & $\mathrm{a}$ & 2 & 0.129 & 419.5 \\
\hline Buiuna & 206,194 & $9,886,658$ & $\mathrm{f}$ & 2 & 0.045 & 220.0 \\
\hline Timboteua & 209,683 & $9,883,338$ & $\mathrm{f}$ & 1 & 0.048 & 138.7 \\
\hline Malva & 230,624 & $9,779,294$ & $\mathrm{c}$ & 1 & 0.001 & 220.2 \\
\hline Água Fria & 240,666 & $9,756,702$ & $\mathrm{f}$ & 2 & 0.008 & 255.7 \\
\hline Uromã & 187,829 & $9,879,133$ & $\mathrm{f}$ & 2 & 0.033 & 100.0
\end{tabular}

$\overline{D C s}$, dominant cover at the local scale (a, agriculture; c, capoeira; f, forest); HS, Horton-Strahler stream order; $C D$, channel discharge $\left(m^{3} s^{-1}\right) ; D A$, drainage area (ha). 


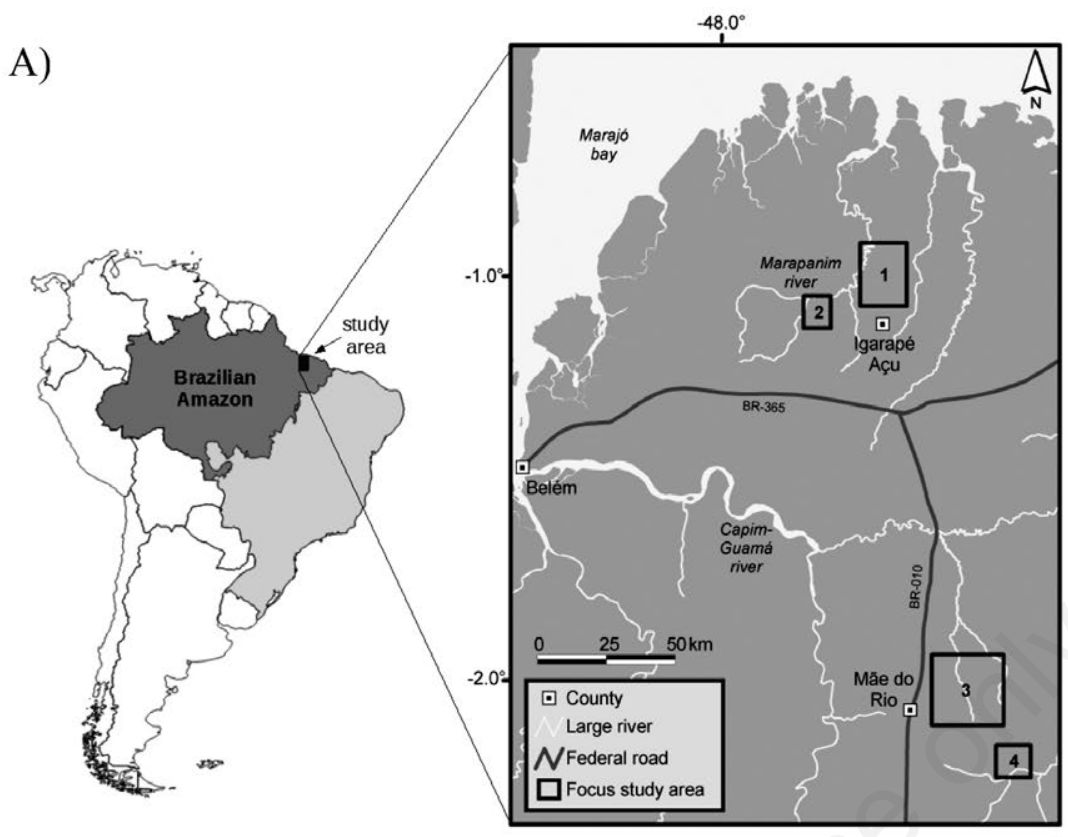

\section{B)}
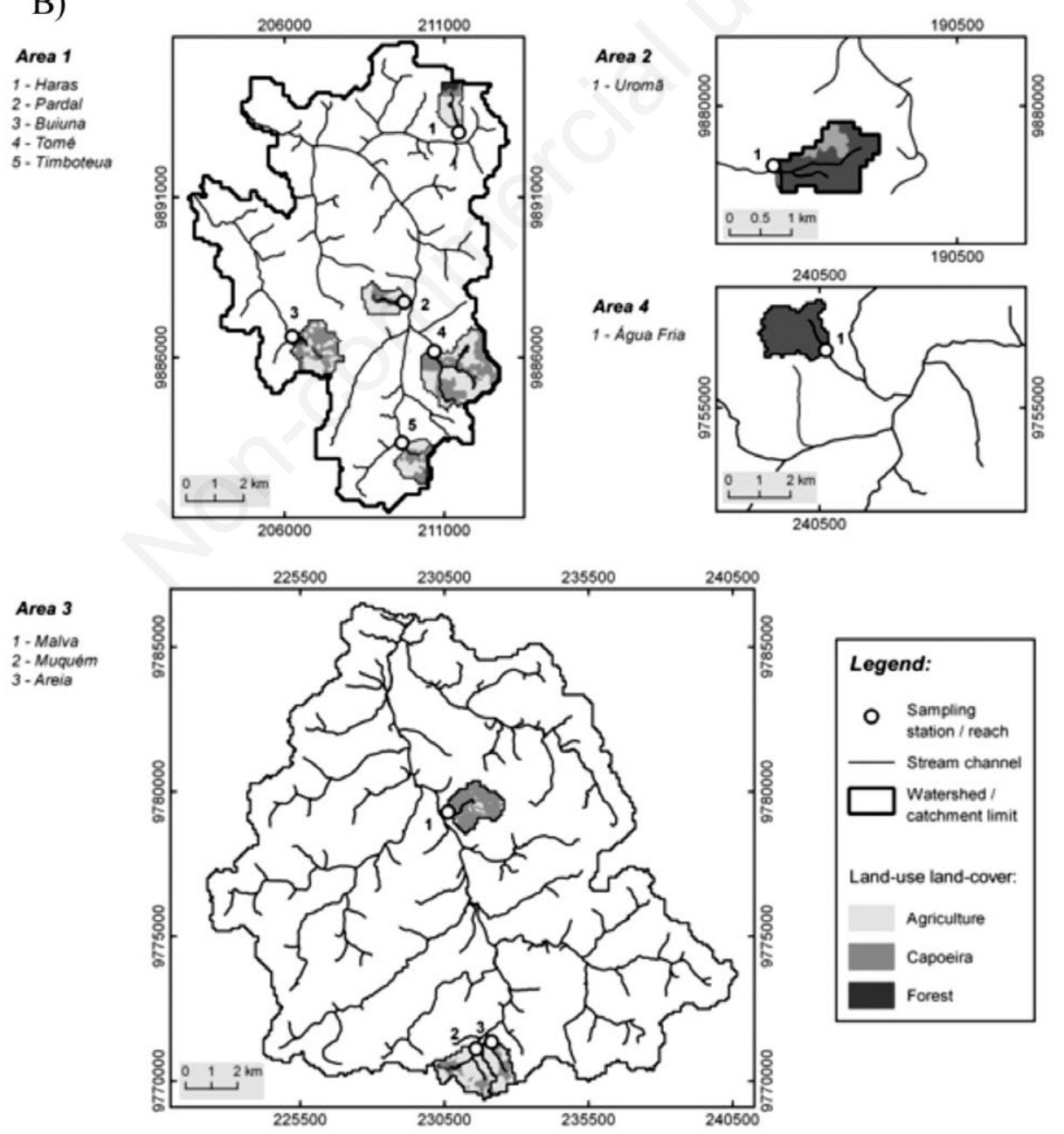

Fig. 1. Location of studied catchments on the Brazilian Amazon and Eastern Amazonia (A) and land-use and land-cover aspects (B). 
Along each of the studied streams, ten Surber samples of two minutes each were taken from sandy or leaf/vegetal debris packs in medium to fast water current habitat units. Three handnet samples were taken from litter patches intertwined to twigs and roots instream. All material was processed immediately by washing it and transferred to bottles containing $4 \%$ formaldehyde for two days and then preserved in a $70 \%$ ethanol solution. Chironomidae larvae were identified into genera using a Brazilian key (Trivinho-Strixino, 2011). Functional feeding groups (FFG) classification followed Silva et al. (2008), Sonoda et al. (2009) and Galizzi et al. (2012).

\section{Data analysis}

Upon taxa identification to genera level, individuals were counted and a Functional Feeding Group was assigned to each taxon. Two Chironomidae abundance matrices were analyzed: total of individuals per genera by stream and total individuals per FFG by stream. Prior to statistical analysis, numerical abundance data were log transformed and, when necessary the abundance matrix was transformed into a distance matrix with the Kulczynski distance. The analysis focused on detecting and describing differences in samples belonging to each of the local riparian dominant LULC category (DCs). First, the homogeneity of multivariate dispersions was analyzed, followed by pairwise comparisons by a permutation test, employing the betadisper and permutest procedures of package "vegan", ver. 2.4.6 (Oksanen et al., 2018). Second, non-metric multidimensional scaling ordinations were constructed with both matrices with the procedure metaMDS. Sample coordinates in dimensions 1 and 2 were related to the DCs variable by a KruskallWallis and Wilcoxon paired comparisons, both non-parametric analyses. Third, these non-parametric techniques were employed to compare the rankedabundance of each of the FFG detected in the samples to the $D C$ factor.

\section{RESULTS}

\section{Chironomidae assemblages}

A total of 20,884 individuals were sampled from the streams, comprising 64 genera. The majority of the genera was of the subfamily Chironominae (37 genera). In Agriculture streams, 58 genera were sampled, followed by 52 genera in Forest and 30 genera in Capoeira. Abundance was higher in Agriculture streams, even if compensated by number of samples: $66.3 \%$ individuals, compared to only $4.9 \%$ in Capoeira streams and $28.8 \%$ in Forest. Corynoneura (18.4\%), Pentaneura (14.6\%) and Rheotanytarus $(14.0 \%)$ were the most abundant at Agriculture streams; Corynoneura (17.8\%), Caladomyia
(13.6\%), Paratanytarsus (13.1\%) and Beardius (10.9\%) dominated forested streams; Goeldichironomus (25.9\%), Rheotanytarus (17.6\%) and Polypedilum (13.2\%) dominated Capoeira streams.

Regarding FFG, gatherers were the most numeric abundant in Forest $(50.3 \%)$, followed by filterers (38.7\%), predators $(6.6 \%)$ and shredders $(4.2 \%)$. In Capoeira, filterers were the main FFG (61.1\%), followed by gatherers $(27.9 \%)$, predators $(7.7 \%)$ and shredders (3.3\%). In Agriculture streams, predators, filterers and gatherers had close numeric participation, $34.9 \%, 32.4 \%$ and $32.2 \%$, respectively. Shredders performed a smaller fraction $(0.4 \%)$. In Forest and Agriculture, scrapers participation was under $0.2 \%$, while it was absent at Capoeira.

\section{Chironomidae assemblage patterns}

The betadisper and permutest procedures revealed significant differences on the homogeneity of multivariate dispersion, either in terms of taxonomic and functional structure (see Fig. 2 for group statistics). Differences among stream groups (Forest $\times$ Capoeira $\times$ Agriculture) in genera composition and abundance was significant: $F=20.527, \mathrm{P}=0.002$ ( 2 and 7 degrees of freedom for group and residuals, respectively); pairwise comparisons indicated significant differences between Forest and Capoeira $(\mathrm{P}=0.012)$ and Agriculture and Capoeira $(\mathrm{P}=0.020)$. Differences among stream groups in $\mathrm{FFG}$ were also significant $(F=5.400, \mathrm{P}=0.034)$ ( 2 and 7 degrees of freedom for group and residuals, respectively); pairwise comparisons showed differences only between Agriculture and Forest groups $(\mathrm{P}=0.027)$.

The NMDS ordinations revealed good 2-dimension solutions for assemblage structure based on both taxonomic and functional aspects (Stress measures were 0.0698 and 0.0274 , respectively) (Fig. 3). The ordination of genera (Fig. 3A) resulted in a clumped distribution of streams of the three main land-uses, while for the FFG ordination, the second dimension presents clearer segregation of such classes. The scores of the ten streams on the two NMDS dimensions were compared among the LULC categories by means of the Kruskal-Wallis rank sum test. The ordination based on FFGs presented significant differences only for NMDS2 (Kruskal-Wallis rank sum test $\mathrm{H}=7.6364, \mathrm{P}=0.02197,2$ degrees of freedom). Subsequent Wilcoxon rank sum test indicated significance only for the Agriculture $\times$ Forest comparison $(\mathrm{P}=0.036)$.

Significant differences in Functional Feeding Groups among groups was revealed only for shredders ( $\mathrm{H}=6.9091, \mathrm{P}=0.0316,2$ degrees of freedom). The pairwise comparisons using Wilcoxon rank sum test revealed significance differences between Forest and Agriculture streams only $(\mathrm{P}=0.036)$. 


\section{DISCUSSION}

The importance of the land-use and land-cover on the environmental quality of streams/watersheds and the associated biota has been documented worldwide during decades (Allan et al., 1997; Davies et al., 2010; French and McCauley, 2018). More recently, negative impacts of agroecosystems lands on streams degradation have been
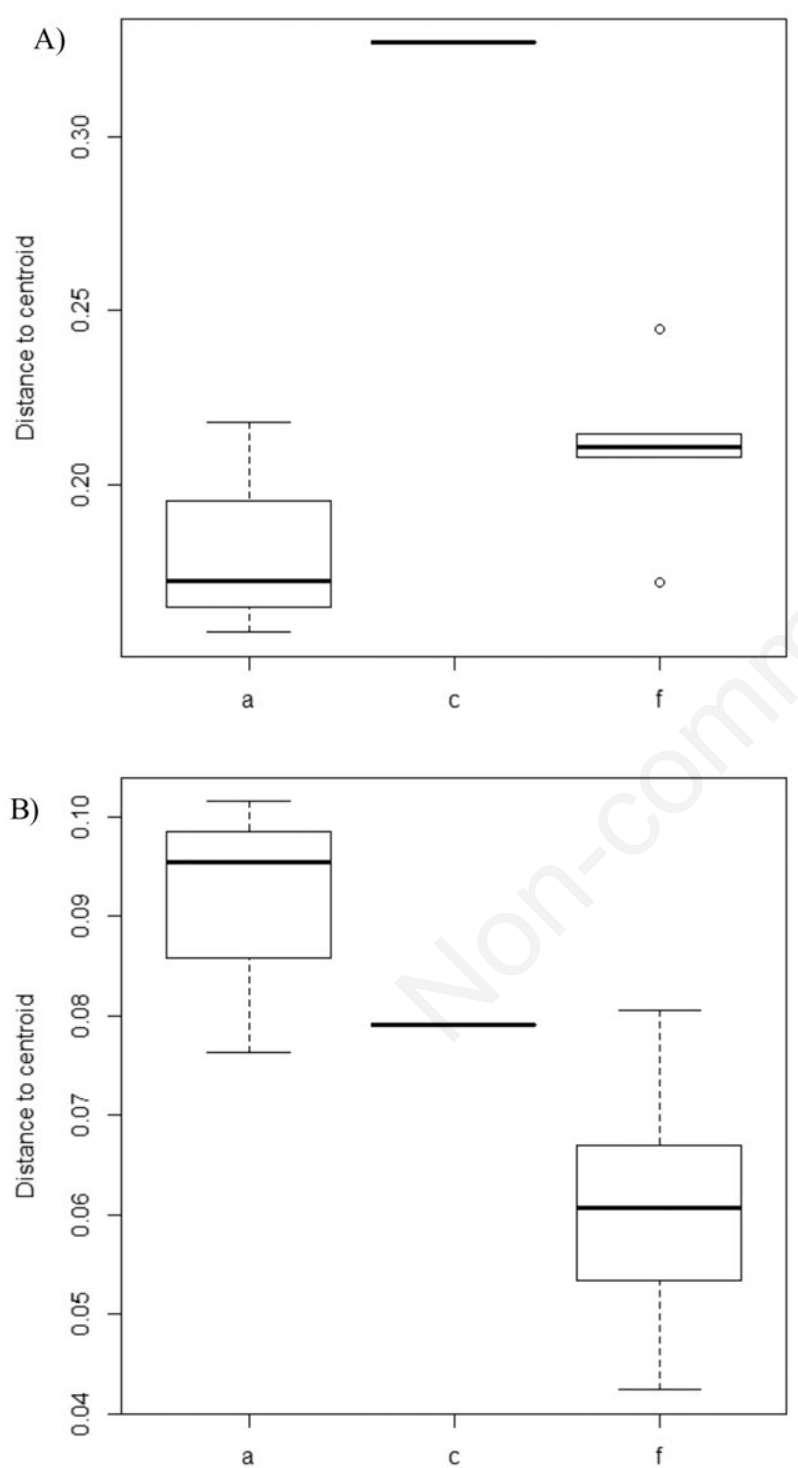

Fig. 2. Box-plots of Chironomidae larvae abundance of individuals in genera (A) and individuals in functional feeding groups (B) compared along Agriculture (a), Capoeira (c) and Forest (f) streams groups. Statistics computed in relation to distance-to-centroids of groups from PCoA ordinations. See text for details. described at the Eastern Amazon region (Leal et al., 2016; de Faria et al., 2017).

Our results showed differences among all three LULC on the abundances of taxonomic composition of genera and FFG and a significant difference between forest and agriculture streams on functional feeding groups, mainly because shredders abundances. The understanding of FFG in relation to LULC changes is an important approach for
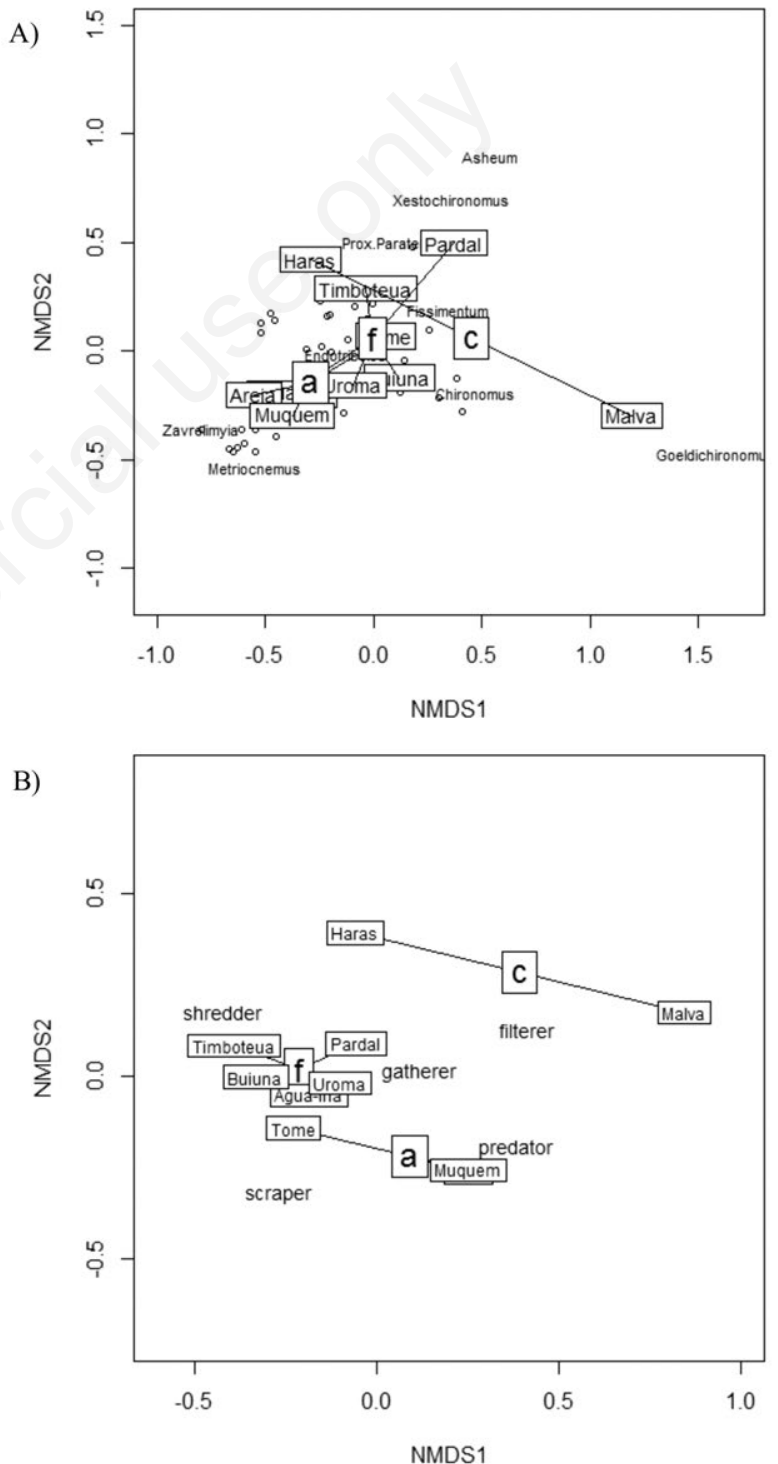

Fig. 3. Ordination plots of NMDS based on Chironomidae genera (A) and functional feeding groups (B). Lines link sample streams (name labels) to centroids of groups (letters). Streams are grouped according to riparian buffer LULC dominance of either Agriculture (a), Capoeira (c) or Forest (f). Labels outside box are selected genera (part A) and functional feeding groups (B). 
a holistic understanding and management of running waters (Montoya et al., 2015; Merritt et al., 2017). Several studies compared the proportion of FFGs in streams (Couceiro et al., 2011; Kohlmann et al., 2015) and some refer to the decrease of shredders at agriculture streams rather than forested ones (Death et al., 2009; Sonoda et al., 2009; Astudillo et al., 2016).

Some explanations are found at the literature to explain the impact of agriculture land-use and land-cover on the aquatic system, such as imbalance of chironomids abundance relative to an increase in the number of agricultural streams (Sonoda et al., 2011; Corbi et al., 2013; Suriano and Fonseca-Gessner, 2013) and sediment addition (Matthaei et al., 2010). Sediment deposition is more pronounced in pasture streams than forested ones (Somura et al., 2012), with significant decrease on shredder abundance (Magierowski et al., 2015), fact also observed on our study. We also registered the imbalance of chironomids quantities on forest to agriculture streams; besides we did not study sediment addition, we observed higher amount of macrophytes at agriculture streams. That is an important fact since studies on other Brazilian regions revealed the increase on Chironomidae abundance related to macrophytes (Sonoda and Trivinho-Strixino, 2000; Trivinho-Strixino et al., 2000), what may explain, along with sediment deposition, the higher Chironomidae participation at agriculture streams.

\section{CONCLUSIONS}

We presented results of Chironomidae from streams at Eastern Amazon, a region which aquatic entomofauna is poorly known. Our study was able to satisfy our goals since the taxonomic richness and abundance changed accordingly to land-use and land-cover on riparian zones (hypothesis 1); and the functional feeding groups (shredders) were appropriate to demonstrate the importance of riparian forest at the streams (hypothesis 2).

Our study is an important contribution to the improvement of regional knowledge and may contribute in land development decisions, since Amazonian region deforestation is increasing to replace forest by agriculture practices. The need for higher amount of agriculture areas should consider the consequences on water quality (locally) and availability (globally, such as La Plata River Basin), as commented at the introduction section.

\section{ACKNOWLEDGMENTS}

The study was supported by the Gestabacias project which was funded by Empresa Brasileira de Pesquisa Agropecuária - Embrapa (\# 02.07.06.017.00), Brazilian National Research Board Council - CNPq (\#
574.648/2008-9) and Amazônia State Research Aid Foundation - FAPESPA (\# 060/2008). Field work was assisted by MSc. Gabriel Lourenço Brejão. Laboratory analyses of water samples were aided by MSc. Camila Silva and PhD. Juliana Felizzolla. Thanks to PhD. Fábio Laurindo da Silva for his kind help. The authors would gratefully thank the Editors and the three anonymous reviewers, whose comments improved the final text.

\section{REFERENCES}

Aguiar APD, Vieira ICG, Assis TO, Dalla-Nora EL, Toledo PM, Santos-Júnior RAO, Batistella M, Coelho AS, Savaget EK, Aragão LEOC, Nobre CA, Ometto JPH, 2016. Land use change emission scenarios: Anticipating a forest transition process in the Brazilian Amazon. Global Change Biol. 22:1821-1840.

Allan JD, Erickson DL, Fay J, 1997. The influence of catchment land use on stream integrity across multiple spatial scales. Freshwater Biol. 37:149-161.

Almeida AS, Stone TA, Vieira ICG, Davidson EA, 2010. Nonfrontier Deforestation in the Eastern Amazon. Earth Interactions 14:1-15.

Armitage PD, 1995. Chironomidae as food, p. 423-435. In: P.D. Armitage, P.S. Cranston and L.V.C. Pinder. (eds.), The Chironomidae: Biology and ecology of non-biting midges. Chapman \& Hall, London.

Astudillo MR, Novelo-Gutiérrez R, Vásquez G, García-Franco JG, Ramírez A, 2016. Relationships between land cover, riparian vegetation, stream characteristics, and aquatic insects in cloud forest streams, Mexico. Hydrobiologia 768:167-181.

Brasil, Código Florestal, 2012 [Lei n ${ }^{\circ} 12.651$ de 25 de maio de 2012].[Text in Portuguese]. Available from: http://www .planalto.gov.br/ccivil_03/_Ato2011-2014/2012/Lei/L12651 .htm

Coe MT, Costa MH, Soares-Filho BS, 2009. The influence of historical and potential future deforestation on the stream flow of the Amazon River - Land surface processes and atmospheric feedbacks. J. Hydrol. 369:165-174.

Corbi JJ, Kleine P, Trivinho-Strixino S, 2013. Are aquatic insect species sensitive to banana plant cultivation? Ecol. Indic. 25:156-161.

Couceiro SRM, Hamada N, Forsberg BR, Padovesi-Fonseca C, 2011. Trophic structure of macroinvertebrates in Amazonian streams impacted by anthropogenic siltation. Austral Ecol. 36:628-637.

Cummins KW, Merritt RW, Andrade PCN, 2005. The use of invertebrate functional groups to characterize ecosystem attributes in selected streams and rivers in south Brazil. Stud. Neotrop. Fauna Environ. 40:69-89.

de Faria APJ, Ligeiro R, Callisto M, Juen L, 2017. Response of aquatic insect assemblages to the activities of traditional populations in eastern Amazonia. Hydrobiologia. doi: 10.1007/s10750-017-3238-8.

Davies PJ, Wright IA, Findlay SJ, Jonasson OJ, Burgin S, 2010. Impact of urban development on aquatic macroinvertebrates in South Eastern Australia: degradation of in-stream habitats 
and comparison with non-urban streams. Aquat. Ecol. 44:685-700.

Death RG, Dewson ZS, James ABW, 2009. Is structure or function a better measure of the effects of water abstraction on ecosystem integrity? Freshwater Biol. 54:2037-2050.

Eltahir EA, Bras RL, 1994. Precipitation recycling in the Amazon basin. Q. J. R. Meteorol. Soc. 120: 861-880.

Ferrington LC, 2008. Global diversity of non-biting midges (Chironomidae; Insecta-Diptera) in freshwater. Hydrobiologia 595: 447-455.

French SK, McCauley SJ, 2018. Canopy cover affects habitat selection by adult dragonflies. Hydrobiologia 818: 129-143.

Galizzi MC, Zilli F, Marchese M, 2012. Diet and functional feeding groups of Chironomidae (Diptera) in the Middle Paraná River floodplain (Argentina). Iheringia Série Zool. 102:117-121.

Gordon ND, McMahon TA, Finlayson BL, Gippel CJ, Nathan RJ, 2004. Stream hydrology: an introduction for ecologists. J. Wiley \& Sons, Chichester.

Kohlmann B, Arroyo A, Springer M, Vásquez D, 2015. Agrirural ecosystem effects on the macroinvertebrate assemblages of a tropical river, p. 299-333. In: Y.H. Lo, J.A. Blanco and S. Roy (eds.), Biodiversity in ecosystems - Linking structure and function. InTech, Rijeka.

Leal CG, Pompeu OS, Gardner TA, Leitão RP, Hughes RM, Kaufmann PR, Zuanon J, Paula FR, Ferraz SFB, Thomson JR, MacNally R, Ferreira J, Barlow J, 2016. Multi-scale assessment of human-induced changes to Amazonian instream habitats. Landscape Ecol. 31:1725-1745. doi: 10.1007/s10980-016-0358-x

Lester RE, Boulton AJ, 2008. Rehabilitating agricultural streams in Australia with wood: a review. Environ. Manage. 42:310326.

Maasri A, Fayolle S, Gandouin E, Garnier R, Franquet E, 2008. Epilithiv chironomid larvae and water enrichment: is larval distribution explained by epilithon quantity or quality? J. N. Am. Benthol. Soc. 27:38-51.

Magierowski RH, Read SM, Carter SJB, Warfe DM, Cook LS, Lefroy EC, Davies PE, 2015. Inferring Landscape-Scale Land-Use Impacts on Rivers Using Data from Mesocosm Experiments and Artificial Neural Networks. PLoS One 10:e0120901.

Matthaei CD, Piggott JJ, Townsend CR, 2010. Multiple stressors in agricultural streams: interactions among sediment addition, nutrient enrichment and water abstraction. J. Appl. Ecol. 47 639-649.

Merritt RW, Fenoglio S, Cummins KW, 2017. Promoting a functional macroinvertebrate approach in the biomonitoring of Italian lotic systems. J. Limnol. 76(s1):5-8.

Montoya D, Yallop ML, Memmott J, 2015. Functional group diversity increases with modularity in complex food webs. Nature Commun. 6:7379.

Ojima DS, Galvin KA, Turner II BL, 1994. The global impact of land-use change. BioScience 44:300-304.

Oksanen J, Blanchet FG, Friendly M, Kindt R, Legendre P,
McGlinn D, Minchin PR, O’Hara RB, Gavin L, Simpson PS, Stevens MHH, Szoecs E, Wagner H, 2018. Vegan: Community Ecology Package. R package version 2.4-6. Available online https://CRAN.R-project.org/package=vegan

Pachêco NA, Bastos TX, 2011. [Boletim Agrometeorológico de 2008 para Igarapé-Açu, PA]. [Report in Portuguese]. Embrapa Amazônia Oriental, Belém: 33 pp.

Silva FL, Ruiz SS, Bochini GL, Moreira DC, 2008. Functional feeding habits of Chironomidae larvae (Insecta, Diptera) in a lotic system from Midwestern region of São Paulo State, Brazil. Pan-American J. Aquatic Sci. 3(2):135-141.

Somura H, Takeda I, Arnold JG, Mori Y, Jeong J, Kannan N, Hoffman D, 2012. Impact of suspended sediment and nutrient loading from land uses against water quality in the Hii River basin. Jpn. J. Hydrol. 450-451:25-35.

Sonoda KC, Trivinho-Strixino S, 2000. [Dinâmica da emergência de Chironomidae (Diptera) da fitofauna de Cabomba piauhyensis Gardney, 1844, na Lagoa do Infernão (Estação Ecológica de Jataí, Luiz Antônio, SP)], p. 743-754. In: J.E Santos and J.S.R. Pires (eds.), [Estação Ecológica de Jataí].[Book in Portuguese]. Publ. RiMa, São Carlos.

Sonoda KC, Matthaei CD, Trivinho-Strixino S, 2009. Contrasting land uses affect Chironomidae communities in two Brazilian rivers. Fund. Appl. Limnol. 174:173-184.

Sonoda KC, Vettorazzi CA, Ortega EMM, 2011. Relationship among landuse and composition of aquatic insects of four basins of São Paulo State. Neotrop. Biol. Conserv. 6:187-200.

Suriano M, Fonseca-Gessner A, 2013. Structure of benthic macroinvertebrate assemblages on a gradient of environmental integrity in Neotropical streams. Acta Limnol. Bras. 25:418-428.

Trivinho-Strixino S, Correia LC, Sonoda KC, 2000. Phytophilous Chironomidae (Diptera) and other macroinvertebrates in the ox-bow Infernão Lake (Jataí Ecological Station, Luiz Antônio, SP, Brazil). Rev. Brasil. Biol. 60:527-535.

Trivinho-Strixino S, 2011. [Larvas de Chironomidae. Guia de identificação].[Book in Portuguese]. UFSCar, São Carlos: $371 \mathrm{pp}$.

Verberk WCEP, van Noordwijk CGE, Hildrew AG, 2013. Delivering on a promise: integrating species traits to transform descriptive community ecology into a predictive science. Freshw. Sci. 32:531-547.

Watrin OS, Gerhard P, Maciel MNM, 2009. [Dinâmica do uso da terra e configuração da paisagem em antigas áreas de colonização de base econômica familiar, no nordeste do estado do Pará].[Article in Portuguese]. Geografia 34: 55-479.

Zemp DC, Schleussner CF, Barbosa HMJ, van der Ent RJ, Donges JF, Heinke J, Sampaio G, Rammig A, 2014. On the importance of cascading moisture recycling in South America. Atmos. Chem. Phys. 14:13337-13359.

Zemp DC, Schleussner CF, Barbosa HMJ, Rammig A, 2017. Deforestation effects on Amazon forest resilience. Geophys. Res. Lett. 44:6182-6190. 